

\section{CONFRONTING IDEOLOGY: ISLAMOPHOBIA VS. ISLAMIST FUNDAMENTALISM}

By Nuzhat Khurshid

M.A. candidate

at York University 


\section{ABSTRACT}

The notions of tradition and modernity organize the contestation of Islamophobia, as a colonialist, capitalist venture originating in the West, as opposed to the 'traditional' forces of fundamentalism, which originate in the East. The print revolution, beginning as a product of colonialist capitalism, led to the explosion and expansion of 'modern' ideas of cultural essentialism whereas the internet revolution has played a strong role in the spread of 'traditional' ideas as defined by Islamist fundamentalism. The apparent 'clash of civilizations'(Huntington 1993) presented by the interaction between the East and the West, or tradition and modernity, will be critiqued and the dangers of these abstractions, which avoid real issues such as class struggle and geopolitical control, will be shown. Finally, some ideas will be presented on how to challenge both these ideologies in their everyday uses. Using Marx's notion of ideology, defined as a tool used by the ruling class to abstract material concepts and maintain power, we will explore the nature of Islamophobia and Islamist fundamentalism.

\section{INTRODUCTION}

As I was formulating my thoughts for this essay, I was saddened by the news of another Muslim 'extremist' who was killed in a foiled terrorist plot. Aaron Driver was shot by police in a taxi cab on August 10 after detonating a bomb. As I continued to read details about his life and views, I felt personally affected by this tragedy. How could an intelligent young man believe his religion allowed him to kill innocents as retribution for crimes committed to people on the other side of the globe? Similarly, how could he feel so alienated while living in Canada that he felt Muslims "did not belong in the West?" (CBC News 2016). It seems that two mutually contradictory ideologies are in place here - a racist and imperialist worldview that promotes the belief that Muslims are different than those living in the West and an equally ethnicized ideology and politics of Islamist fundamentalism. These ideologies are also deeply intertwined with the concepts of 'tradition' and 'modernity', European concepts created in the course of capital's development in Europe and its expansion into the rest of the world. But how to disconnect from these flawed ideologies that threaten to divide the world, and to understand the underlying problems?

Marx's writing on the nature of ideology can offer an important and relevant lesson for this problematic. Marx's use of ideology is unique in that it is meant for 'radicals', or those who wish to change the world, not just interpret it (Marx 1978, 145). Thus, he is interested in the ways by which ideology is used by the ruling class to legitimize power structures and take the focus away from class struggles and interests. A closer examination of Marx's works will help explain his views from a historical materialist perspective. In his preface to 'A Contribution to the Critique of Political Economy, Marx writes, "A distinction should always be made between the material transformation of the economic conditions of production, which can be 
determined with the precision of natural science, and the legal, political, religious, aesthetic or philosophic - in short, ideological forms in which men become conscious of this conflict and fight it out" (Marx 1978, 5). Furthermore, he recognizes that these forms of ideology can be used by the ruling class to enforce and legitimize their control, as when he says, "The ideas of the ruling class are in every epoch the ruling ideas" (Marx 1978, 172). He explains, "For each new class which puts itself in the place of one ruling before it, is compelled, merely in order to carry through its aim, to represent its interest as the common interest of all the members of society, that is, expressed in ideal form: it has to give its ideas the form of universality, and represent them as the only rational, universally valid ones" (Marx 1978, 174).

As Bannerji explains, these 'ruling ideas' manifest themselves in society in various ways: "Not only particular concepts or ideas, but the very deployment of concepts, even daily expressions in their de-materialized, de-historicized and unreflexive uses, gives rise to Ideology" (Bannerji $2011,8)$. She goes on to give the binaries of tradition/modernity as an example of a current ideology which dominates world relations. She explains that, "Capitalist colonialism's staple categories are modernity and tradition, in their active form becoming modernization and traditionalism, claimed to be resistance to modernization" (Bannerji 2011, 22). The problem of the competing ideologies of 'modern' imperialism and 'traditional' fundamentalism posed at the beginning of this paper is a strong example of how these 'ruling ideas' can play out negatively and deflect attention from the real, material problems behind them.

Thus the notions of tradition and modernity organize the contestation of Islamophobia, as a colonialist, capitalist venture originating in the West, as opposed to the 'traditional' forces of fundamentalism, which originate in the East. It is important to note that 'tradition' is always defined as the space in which modernity does not reside, as opposed to being a separate, identifiable concept in its own right; this is a reflection on the binary nature of these concepts. This will be important when we talk about the politics of Islamist fundamentalism as being a reaction to capitalist, colonialist encroachments, as opposed to originating naturally within Islamic thought. We will also explore how the print revolution, beginning as a product of colonialist capitalism, led to the explosion and expansion of 'modern' ideas of cultural essentialism whereas the internet revolution has played a strong role in the spread of 'traditional' ideas as defined by Islamist fundamentalism. The apparent 'clash of civilizations' presented by the interaction between the East and the West, or tradition and modernity, will be critiqued and the dangers of these abstractions, which avoid real issues such as class struggle and geopolitical control, will be shown. Finally, some ideas will be presented on how to challenge both these ideologies in their everyday uses. Using Marx's notion of ideology, defined as a tool used by the ruling class to abstract material concepts and maintain power, we will explore the nature of Islamophobia and Islamist fundamentalism. 


\section{EMERGENCE OF ISLAMOPHOBIA}

While Islamophobia will be shown here as having origins in Orientalism, it is important to acknowledge that the term 'Islamophobia' is a highly contested one and has been studied by various authors (See Christopher Allen, 'Islamophobia' (Allen 2010, 187-92)). Like any other kind of racism, it is a combination of behaviours, attitudes and ideologies that attempt to demean and discriminate against Muslims for the sole reason of their religion. For this paper, however, it will be helpful to focus on the ideological component of Islamophobia in order to show its resonance with past ideologies and the legacy of colonialism.

The ideologies of tradition and modernity have their origins in the age of colonialism, which is deeply intertwined with the ever-expanding needs of capitalism (Luxemburg 1951, 416-7). Needing to justify their moral superiority as colonizers, the notions of traditional peoples arose and "its organizing assumptions centre around the concept of cultural difference between the colonizing and colonized societies" (Bannerji 2011, 230). Edward Said has perhaps articulated this cultural essentialism best in his book Orientalism. He attempts to explain the evolving ideology of Orientalism as:

"a distribution of geopolitical awareness into aesthetic, scholarly, economic, sociological, historical, and philological texts; it is an elaboration not only of a basic geographical distinction (the world is made up of two unequal halves, Orient and Occident) but also of a whole series of 'interests' which... it not only creates but also maintains" (author's emphases) (Said 1979, 12).

Thus we see that Said defines Orientalism as a kind of cultural essentialism accompanied by socio-economic power structures and dictated by the ruling ideas. These implied differences between the Orient and the Occident, or the East and the West, come to take on the guise of truth largely due to the impact of capitalist colonial ventures and the far-reaching influence of the printing press. Said explains that "[there] was a growing systematic knowledge in Europe about the Orient, knowledge reinforced by the colonial encounter as well as by the widespread interest in the alien and unusual, exploited by the developing sciences of ethnology, comparative anatomy, philology and history" (Said 1979, 39-40) In fact, the emergence of capitalist colonialism and the global spread of the printing press starting in the 16th century are closely related. Anderson reiterates the connection between "capitalism's restless search for markets" and the success of the European publishing press (Anderson 1983, 38).

It will be shown that notions of the 'traditional' Easterners were vastly facilitated by colonial capitalist ventures and the dissemination of a special construction of cultural knowledge of the East by the West. Said defined this cultural currency as Orientalism while Samir Amin calls it Eurocentrism. This current gained influence through imperialist policies and knowledge production, and by the 19th century, "an assumption had been made [by the West] that the 


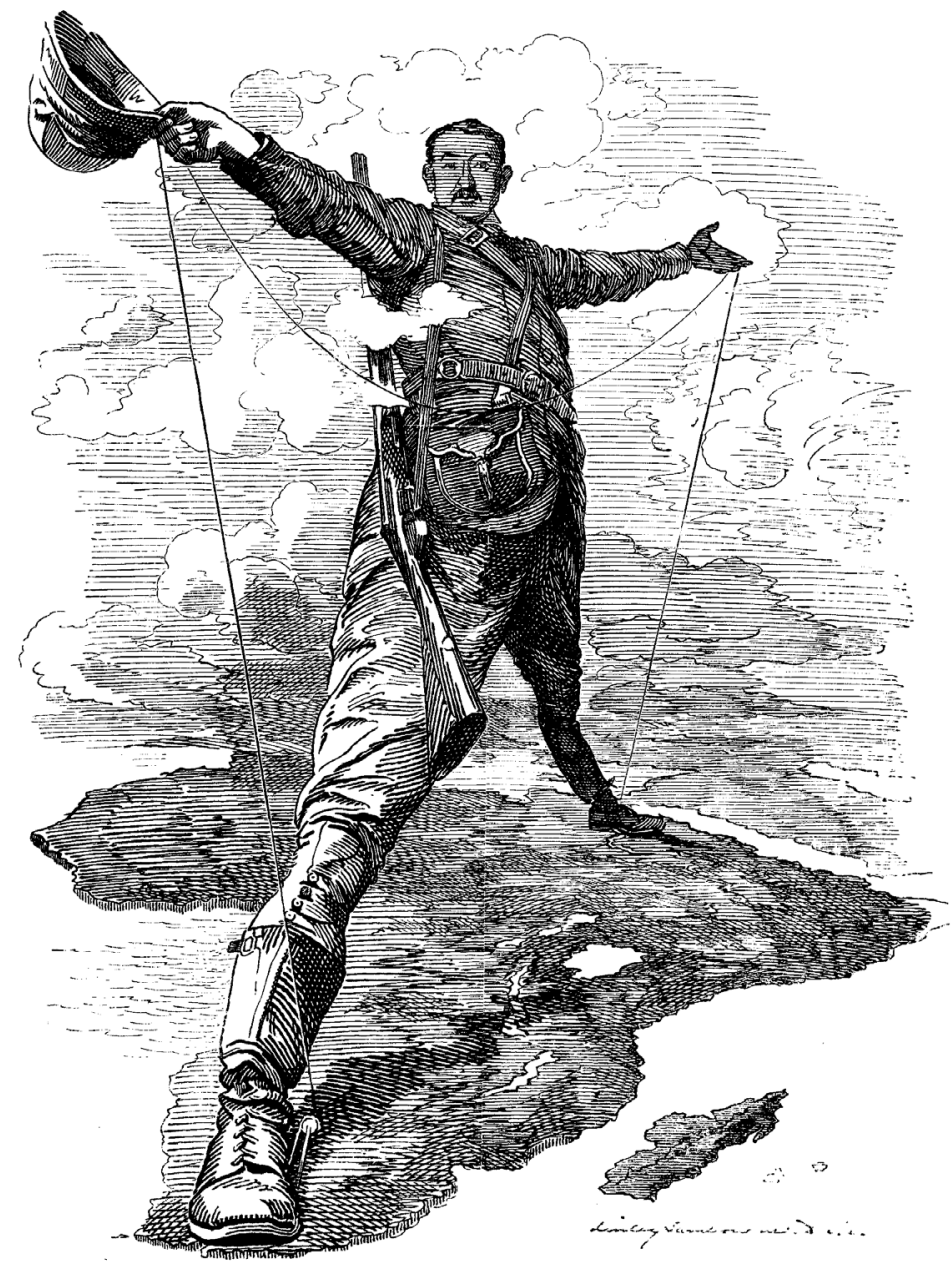

The Rhodes Colossus, a cartoon of Cecil Rhodes representing British colonialism and the Scramble for Africa. (Drawing: Edward Linley Sambourne)

Orient and everything in it was, if not patently inferior to, then in need of corrective study by the West" (Said 1979, 41). The West became the harbinger of modernity, or European capitalism, and all its benefits, while the East was viewed as backwards and in need of European beneficence. The expansion of Orientalist knowledge, often funded directly by European governments and academic institutions, created a binary that strengthened itself and came to be accepted as truth. 
Said pinpoints this dilemma as follows: "When one uses categories like Oriental and Western as both the starting and the end points of analysis, research, public policy... the result is usually to polarize the distinction - the Oriental becomes more Oriental, the Westerner more Western - and limit the human encounter between different cultures, traditions, and societies" (Said 1979, 46). To see how this mindset has been nurtured through successive encounters between the East and West, one need look no further than Samuel Huntington's 'Clash of Civilizations' thesis, first published in 1993.

In his much-acclaimed article, he posits that 'civilizations' will be the determinants of conflict in the future: "The fault lines between civilizations will be the battle lines of the future" (Huntington 1993, 22). Although he differentiates civilizations from ideology and culture, he does not explain how exactly he plans on dividing up people into these abstract groups. Civilizations are "the broadest level of cultural identity people have short of that which distinguishes humans from other species" (Huntington 1993, 24). Huntington further qualifies his use of 'civilization,' defining it "both by common objective elements, such as language, history, religion, customs, institutions, and by the subjective self-identification of people" (Huntington 1993, 23). This further complicates the task of discovering a concise definition of the word, because the categories he lists are not only too vague and large, but closely related and overlapping. Moreover, the average American or European is still more likely to identify $\mathrm{him} /$ herself based on gender, nationality, religion or occupation, than on a vague conception of 'civilization' such as 'Western.'

Complex and intertwining identities cannot be reduced to monolithic categories. By placing the full weight of his theory on the assumption of abstract civilizational identity, Huntington debilitates its credibility. The 'clash' of which Huntington speaks of so deterministically, can actually be explained far more convincingly by a historical materialist perspective of history, in which class, economic, and political factors play the larger role in and through forms of social relations and consciousness which we may call 'culture.' Constructing international conflicts as based on cultural lines further reiterates the colonial binary of the West and the rest, where the Other is inherently inferior and must be ruled for their own good.

\section{While it is true that most Muslim countries in contemporary times are suffering from poverty and political instability, to use this as proof of the Other's lack is to be blind to the West's own complicity in the creation of this inequality.}

Furthermore, Huntington's categorization of 'Islam' as a civilization is not consistent with his treatment of other religions (Huntington 1993, 25). Why is Islam handpicked for prominence among civilizations while the other great world religions (aside from Hinduism) are subverted 
by other, 'broader' entities? Surely a Christian or Jew feels just as strongly about his/her faith and legitimizes and encourages intolerance. Said's Orientalism is indeed alive and well in Huntington's formulation. Instead of encouraging open communication and understanding between the 'civilizations,' Huntington portrays a future where the noble 'West' must swoop down and rescue the other barbarian culture from self-destruction. "Islam has bloody borders" (Huntington 1993, 34) he writes in one place, describing how Muslims in the Middle East and Africa have spilled the blood of all their surrounding neighbours, with no mention of any reciprocal conflict or history of European violence. Huntington's parochialism and partiality are revealed through his unconditional support for the West and its imperialistic tendencies, justified by its superiority in all respects: "It is clearly in the interest of the West to limit the expansion of the military strength of Islamic states; to exploit differences and conflicts and to strengthen international institutions that reflect and legitimate Western interests and values" (Huntington 1993, 49).

September 11th, 2001 served as a benchmark for the latent Orientalism that had existed since the 1500's (or earlier) to come to the surface in the form of 'Islamophobia." "The enemy of America is not our many Muslim friends" (Toronto Star 2001) said George W. Bush shortly after the attacks. But hate crimes against the Muslim population in the U.S. increased by 1,700 percent in the remainder of that year alone (Human Rights Watch 2002). The discrepancy between official jargon and actual practice can be attributed to a rising suspicion of Muslims in the West as being 'extremists' living among the innocent. "The carefully planned and horrendous, pathologically motivated suicide attack and mass slaughter by a small group of deranged militants has been turned into proof of Huntington's thesis," writes Said (Said 2001). Even the well-established British weekly, The Economist, in the issue immediately following the attacks, praised Huntington for his "cruel and sweeping, but nonetheless acute" (The Economist 2001) observation about the West-Islam divide. Was this the beginning of a new era of suspicion and paranoia between the two 'civilizations'? Looking back in hindsight, the answer appears to be in the affirmative.

To summarize the ideology of Islamophobia and the history leading up to it, what started as imperial justification of colonialism in the 1500's evolved, through direct intervention and the subconscious reiteration of ideas into the paradigm of Orientalism, which defined the East and West as diametrically different entities, with the West being superior in all respects. Since the terrorist attacks of September 11, it seems the mostly latent ideology of Orientalism, or Eurocentrism, has evolved into a political ideology better understood as 'Islamophobia,' thathas far-reaching effects on public policy and media portrayal of Muslims. I argue that the print revolution played a major role in spreading these ideas throughout the world. 
The ideology of Islamophobia is thus an abstraction that homogenizes Muslims and fails to acknowledge the diversity within Islam. Thus the actions of one extremist are easily applied as a representation of all Muslims within media, which ultimately has a detrimental effect on the rights of Muslims living in the West. From bills that allow the indefinite detention of suspected 'terrorists' to regular attacks on Muslim women's apparel, it seems that the Orientalist gaze is now the norm. Razack confirms, "Race thinking, the denial of a common bond of humanity between people of European descent and those who are not, remains a defining feature of the world order" (Razack 2008, 6). For Muslims living in the West, they are told that they must choose between their Muslim and Western identities. Thus the ideology of what is now known as 'Islamophobia' diverts attention from the real issues and class struggles of Muslims in the West, most of who are children of immigrants. We can challenge this ideology by educating others not to accept media portrayals of 'others' at face value. As students and future educators, those in academic fields can work to question the status quo and use methodologies, such as that of Marx, to focus on real, existing problems rather than abstract theories, however popular they may be.

\section{EMERGENCE OF ISLAMIST FUNDAMENTALISM}

Now that we have discussed the origins of Islamophobia and its relationship to the 'modern' notions of imperialist capitalism, let us turn to the equally 'racist' political ideology of Islamist fundamentalism, and try to understand it as a representation of 'tradition.' As Bannerji explains, the notion of tradition has come to be understood in hindsight, in relationship to its counterpart, modernity:

"If contemporary Europe were to be modern, non-Europe was perforce to be traditional. Defined economically as pre-or non-capitalist, culturally bound by iron rules of religion, ritual and hierarchy, politically under despots and warlords, locked in isolated village communities, resisting urbanization and reveling in particularist consciousness - a grand discourse expanding into a paradigmatic discourse of the East or traditional society became hegemonic" (Bannerji 2011, 234-5).

As we can see, the East is ideologically constructed as the non-West, and the traditional. In this binary, Islamic representations, or "ideal types" (Weber 1992, 33) represent what is worst in the East: "The... ideal types in the complex of the orient are the fanatic Islamic fighters - coming down to us from the days of the crusades... Then there are the Islamic assassins and villains,... the Muslim priest, [and the passive Muslim] women” (Bannerji 2011, 251). In the modern day, these representations take on different forms, from stereotypes about the suicide bomber, the jihadi and the 'terrorist,' a word which comes with its own contradictions (Bannerji 2011, 251-2). 


\section{The 'Islamist terrorist' of today seems to fit perfectly within the image of the violent, irrational Orient from centuries ago. Is it then a coincidence that Islamist extremists are choosing to combat what they see as immoral imperialism with this ideology?}

I believe there is more to the picture than meets the eye. As Bannerji explains, "Tradition and modernity are cultural and not social or historical. In fact they are value categories, categories of moral/cultural/aesthetic judgment. This is what implicates them... into relations of ruling, of capital, class, colonialism and imperialism. Depending on the political standpoint, 'tradition' or 'modernity' becomes the value of choice" (Bannerji 2011, 251-2). Thus if modernity has aligned itself with capitalism, imperialism and the promotion of Western values over Oriental, 'Islamic' ones, it is not a coincidence that fundamentalists would choose to take refuge in traditional values, the most extreme of which is the Wahabbi fundamentalist interpretation of Islam which is rejected by most Muslims. It seems both sides agree that one extreme ideology must be combatted with another equally extreme and xenophobic ideology. These ideological binaries also seek to homogenize both sides and do not show their intermingling, where 'Islamist fundamentalists' may also very immersed in Western culture and Western 'imperialists' may actually be sympathetic to Muslims.

Moreover, almost all of the 'religious' extremism that we see today in the Muslim world has its roots in reactions to political grievances incurred by the West, through capitalist imperialism and political aggression. We will also see that, just as the print revolution strengthened the spread of Orientalist ideas, the internet revolution is the main method through which extremists have been able to promote their interests and reach a wider audience. Modes generated by capitalism itself are thus being used to fight back against the hegemony of capital. All of this is symptomatic of the hazards of ideology, in which real, everyday issues are occluded by abstract ideologies which vilify the 'other' and justify violence.

If we use the Marxist method of starting with particulars as opposed to the general, I want to take the argument back where it started, to the case of Aaron Driver. When asked how he became radicalized after converting to Islam, he attributed it to the atrocities he had read about on the internet occurring in the Middle East at the hands of the West: "Seeing some of the things that happened in Syria, it infuriates you and it breaks your heart at the same time. And I think that if you know what's going on, you have to do something. Even if you're just speaking about it" (CBC News 2016). This is a compelling statement because it speaks to the nature of ideology as something grounded in the practical and political as opposed to the theoretical, as well as the complicity of the internet in spreading these ideologies. 


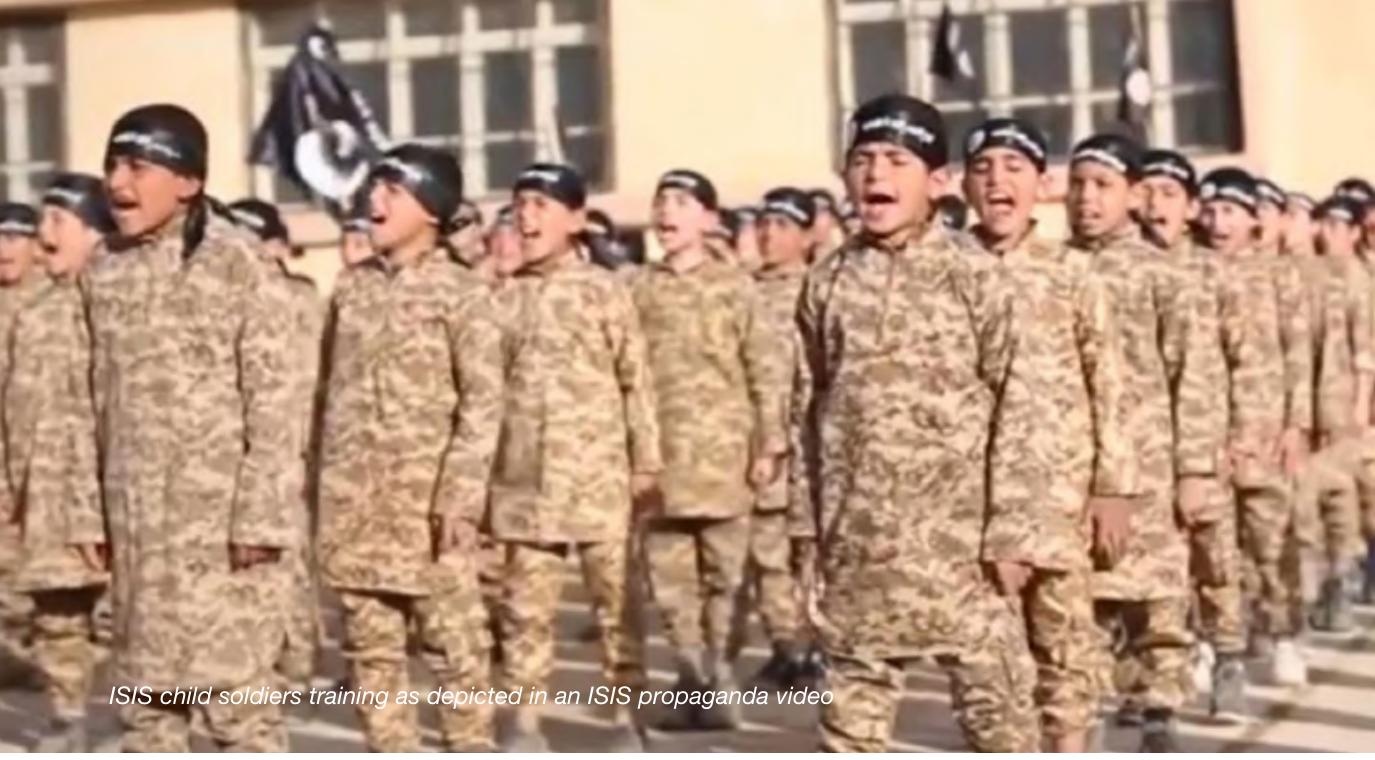

Even major fundamentalist leaders will ground their rationale in the injustices committed against Muslims by the West, rather than religious justification to kill non-Muslims. After the attacks in Paris last year, a French Islamic State of Iraq and al-Sham (ISIS) militant incited other French Muslims to attack civilians as retribution for France's air strikes in Syria in the following words: "Jihad is the path of Allah. You strengthen their economy and pay taxes which they use to fight us, and kill our sisters, our women and our children" (Times of Malta 2015). In 2010, even Osama Bin Laden justified Al-Qaeda’s violence by asking the West, "How is it right for you to occupy our countries and kill our women and children and expect to live in peace and security?" (Davis 2011). It is evident that however much the conflicts of the world are couched in grand ideologies, their raison d'etre remains grounded in the everyday lives and security of people, and a long history of cultural and practical domination by the West. In the words of Neumann, "Without grievance, ideology does not resonate, while without ideology, grievances are not acted upon” (Neumann 2011).

Currently, ISIS is the face of global Islamist fundamentalism, replacing Osama bin Laden and the Taliban, or at least the one currently receiving the most news coverage. The formation of this extremist group is directly linked to the fallout and instability created by George W. Bush's war on Iraq in 2003 under the pretense of finding 'weapons of mass destruction.' The war destabilized the region and fueled the rage felt by extremists at yet another aggression against a Muslim population. This resentment, "formed along contemporary fault lines of power and patronage, drove a widespread Sunni resistance, a mix of non-ideologues enraged by losing jobs, status and dignity, and others, like the jihadis, who believed the war had been preordained in Islamic prophecies" (Chulov 2015). The latter group eventually formed the Iraqi branch of ISIS, and gained followers from the disillusioned masses who had been affected by the war. Thus ISIS was formed not as an organic evolution within Iraqi and Syrian 
politics, but as a direct consequence of Western imperialism in these Muslim-majority lands, as well as divide-and-rule policies covertly initiated in these countries to create strife between different sects and sub-groups.

Moreover, ISIS would not have been able to gain the influence it has without modern technology, especially the internet. Using almost every social 'app' available, from Facebook to WhatsApp, ISIS has been able to win most of its wars in the virtual arena. "ISIS has truly disrupted the very notion of war. We don't need tanks and guns to destroy this enemy as much as we need technology and data" (Bilton 2016). Most of the foreign followers of ISIS, who are likely to carry out attacks in the West, are inspired by ISIS propaganda on the internet. Recently the Canadian government issued a report citing that the terror threat in the country had not significantly increased, and the main threat remained those who were inspired by online extremist content to attack (Boutilier 2016). When ISIS began their beheading campaign of foreign journalists, they publicized their attacks through videos posted on the internet. When ISIS claims responsibility for an attack, they use their Twitter account, with followers re-tweeting its messages. ISIS retains a hugely popular social media presence, with rapidly growing numbers of followers. In fact, this is one of the reasons anti-terrorist experts are unable to verify the strength of ISIS, since it is hard to ascertain the number of followers through their Twitter handles alone (Bilton 2016). Just as the spread of modern Orientalist ideas was greatly strengthened by the rapid increase in the publication of books, the Islamist fundamentalists of today are using 'traditional' values of extremist Islam (as had been defined by Orientalist perceptions of the savage Muslim) mixed with capitalist modes of communication, mainly the internet, to strengthen their global presence. It can be argued that ISIS would have very few followers if it were not for its strong online presence and manipulation of social media for its own interests. We find the forces standing for 'tradition' are using modes of capitalism, as well as the social relations of capital, to fight the forces of what they perceive as the immoral West, or modernity, which has its roots in capitalist imperialism. Perhaps this is evidence of the limitations of capitalism, which Weber saw as an 'iron cage' that would become a liability for the global economic order. Or perhaps we can see that modes of communication are the only means by which to spread ideology, and these modes are usually in the hands of the wealthy who control them. It also shows that the categories of the 'West' and 'Islamist fundamentalism' are not as diametrically opposed as they are made to seem and both groups may actually borrow from the others' ideas and tools.

\section{CONCLUSION}

It has been shown that Islamist fundamentalism, as a current representation of 'tradition, is trying to battle the forces of Western imperialism, or 'modernity.' Just as the ideology of Islamophobia homogenizes all Muslims as being violent and irrational, Islamist fundamentalists portray all those who live in the West as amoral aggressors. 


\section{Both groups see 'culture' as a fixed, static phenomenon and are guided by the notion of cultural 'purity' and not fluidity. Since these extremists are reacting to 'modern' forces of imperialism, as well as to Orientalist stereotypes, eliminating fundamentalism will involve eliminating both these causes.}

In the absence of this, those who are drawn to fundamentalism within the Muslim world would do well to heed Frantz Fanon's advice to re-direct their anger into productive social and political means instead of violence which defeats their purpose and only reinforces their negative stereotypes.

Here, we can discuss how Muslims, who do not represent any territorial dimension, can come to be defined as a 'nation' and thus benefit from Fanon's prescription for the liberation of oppressed 'nations.' I will argue that Islam is unique in that its membership is based on the knowledge of the Arabic language. The first English translation of the Qur'an came into existence more than 1000 years after the book was revealed (historyofislam.com). Even though there are translations in every language readily available now, the original language is still revered and learned by Muslim children across the globe. Benedict Anderson shows that language is primordial and can create 'nations' even without territorial borders: "Much the most important thing about language is its capacity for generating imagined communities, building in effect particular solidarities... Languages thus appear rooted beyond almost anything else in contemporary societies" (Anderson 1983, 133-45). Through the careful preservation of the Arabic language, in print as well as in basic social etiquette, it is possible to create a global Muslim community with shared values.

If we agree that Muslims may view themselves as a nation, what would Fanon say about how Muslims today can challenge extremism? In 'Wretched of the Earth', he outlines a way by which the oppressed nation, which is justifiably angry, can channel that anger in productive ways for the achievement of a common good. "We shall see that for a man who is in the thick of the fight it is an urgent matter to decide on the means and the tactics to employ: that is to say, how to conduct and organize the movement. If this coherence is not present there is only a blind will toward freedom, with the terribly reactionary risks which it entails" (Fanon 1963, 59). Although Fanon does give an important role to violence, it is as a last resort and in self-defence. This is timely advice for those Muslim fundamentalists who feel that violence is the only way to be seen and heard. In order to form this coherence, Fanon believes we need to decolonize our minds from the seeds of both ideologies - Orientalist stereotypes about the about the violent Muslim, as well as the fundamentalist views that would justify violence - in order to use their anger in practical and political ways to enact change in struggling Muslim countries. In fact, using Islam as a means to combat Islamist extremism may be among the 


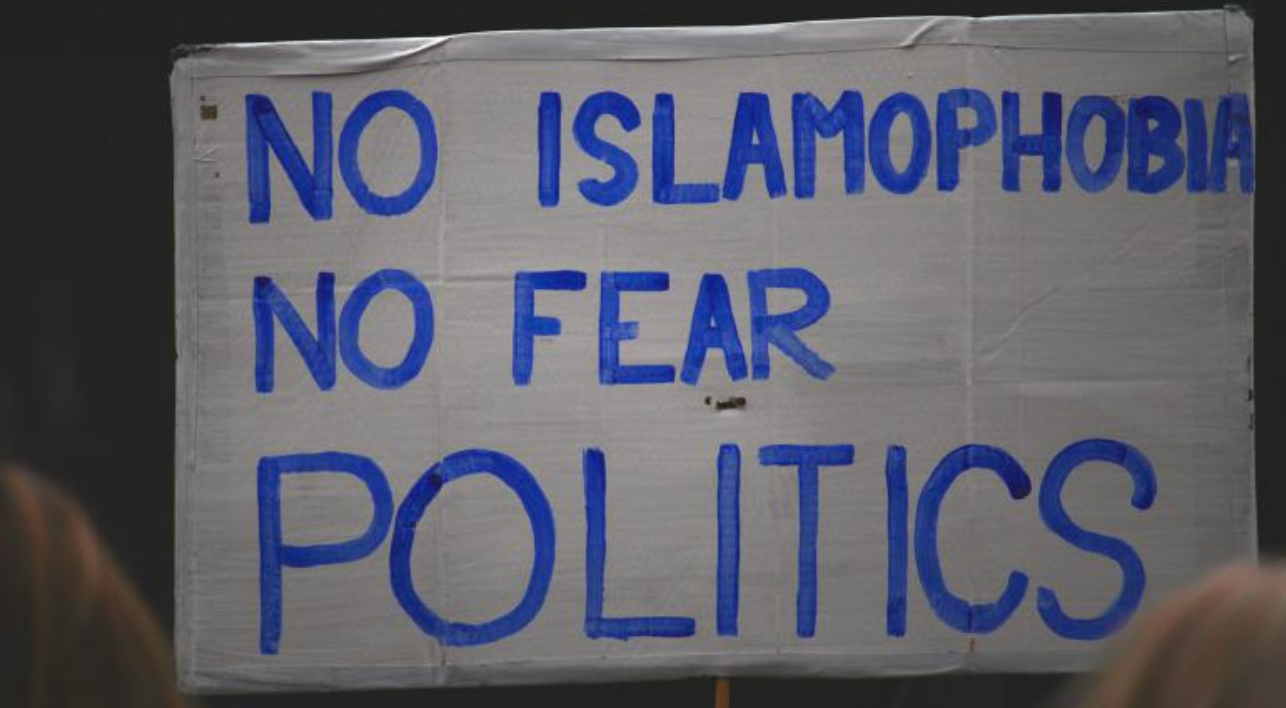

Photo from a Bill C-51 protest (Photo: Flickr/JMacPherson)

best strategies as study after study has shown that religious observance and radicalization are not causative and in fact, work against each other (Hellyer 2016).

To summarize, Marx's notion of ideology can be used to understand the current conflict between Islamophobia, which has its roots in a colonial, capitalist version of modernity in the West, and the traditional fundamentalism of the East. Moreover, Orientalist views were spread in large part due to the print revolution, while fundamentalist views are being promoted largely through the internet revolution. The hazards of both these ideologies are the abstractions which deflect attention from real, material issues. As Bannerji says, "We need to tackle this issue epistemologically - as a particular mode of production of knowledge, which inevitably produces a degrounded, a dehistoricizing set of concepts, categories and meanings which erase, occlude, reify, distance or displace the historical and the social" (Bannerji 2011, 236). We must challenge these ideologies which threaten to destroy peace and the natural affinity between peoples. It is only then that Muslims such as Aaron Driver will be able to recognize the false ideology of Islamophobia which alienated him socially, as well as the false ideology of fundamentalism, which took his life unnecessarily.

Nuzhat Khurshid is an M.A. candidate at York University. She is interested in the way that mainstream International Relations problematizes certain identities by relying on notions of Western cultural imperialism that essentialize the Other. She wants to explore how subject formation and order co-constitute each other, depending on Othering processes that suffocate rather than open up space to think and recognize others as legitimate leaders and decision-makers of the global order. Using critical approaches to IR, such as postcolonial theory and narrative, she hopes to understand how we can step outside of contemporary fault lines around polarized identities and create a more ethical political world. 


\section{BIBLIOGRAPHY}

"Aaron Driver: Troubled childhood, ISIS supporter, terror threat suspect." CBCNews, 10 August 2016, http://www.cbc.ca/news/canada/manitoba/aaron-driver-troubled -childhood-isis-supporter-1.3716222. Accessed 1 September 2016.

Allen, Chris. Islamophobia. Ashgate, 2010.

Anderson, Benedict. Imagined Communities. Verso, 1983.

Bannerji, Himani. Demography and Democracy: Essays on Nationalism, Gender and Ideology. Canadian Scholars' Press and Women's Press, 2011.

Bilton, Nick. "How ISIS became the world's deadliest tech start-up." Vanity Fair. 20 June 2016. Accessed 2 Sep. 2016.

Boutilier, Alex. "Main threat to Canada comes from lone wolves, those inspired to attack: Report.” Toronto Star, 25 Aug. 2016. Accessed 2 Sep. 2016.

Bush, George W. “Address to Congress,” Washington, Toronto Star, 21 Sep. 2001. Accessed 2 Sep. 2016.

Chulov, Martin. "Tony Blair is right: Without the Iraq War there would be no Islamic State." The Guardian. 25 Oct. 2015. Accessed 2 Sep. 2016.

Davis, Rowenna. "Bin Laden: the war in his words." The Guardian. 2 May 2011. Accessed 2 Sep. 2016.

"Enemies Within, Enemies Without." The Economist, 20 Sep. 2001. Accessed 2 Sep. 2016.

Fanon, Frantz. The Wretched of the Earth. Grover Press, 1963.

“France Remains Top Target: IS.” TimesofMalta.com. 15 Nov. 2015. Accessed 2 Sep. 2016.

Hellyer, H. A. "Observance of Islam is a way to defeat extremism." The National. 25 Feb. 2016. Accessed 1 Mar. 2017.

Huntington, S. P. (1993). The clash of civilizations? Foreign Affairs, 72(3), 22.

Luxemburg, Rosa. The Accumulation of Capital. Translated by Agnes Schwarzschild, Routledge and Kegan Paul Ltd, 1951. 
Marx, Karl. The Marx-Engels Reader, 2nd ed, Edited by Robert C. Tucker, W.W. Norton \& Company, Inc., 1978.

Neumann, Peter. "Policy Analysis." The Washington Institute. January 7, 2011. http://www. washingtoninstitute.org/policy-analysis/view/combating-violent-extrerism-the -counterradicalization-debate-in-2011.

The Qur'an, History of Islam, https://historyofislam.com/the-quran/, Accessed 4 November 2016.

Razack, Sherene H. Casting Out: The Eviction of Muslims from Western Law and Politics. University of Toronto Press, 2008.

Said, Edward. Orientalism. Vintage Books, 1979.

“U.S. Officials Should Have Been Better Prepared For Hate Crime Wave," Human Rights Watch, New York, 14 Nov. 2002, http://hrw.org/pressl2002/1 1/usahate.htm. Accessed 2 Sep. 2016.

Weber, Max. The Protestant Ethic and the Spirit of Capitalism. Routledge, 1992. 